\title{
The Contribution of the German Neukirchen Mission (GNM) in the advent of Western Education in Tana River County, Kenya 1885-1986
}

\author{
Gitonga P. Kimani- Ph D Student and Tutorial Fellow, Kenyatta University \\ Professor James E. Otiende- Kenyatta University \\ Professor Augustine M. Karugu- Kenyatta University \\ Department: Educational Foundations \\ Email:kimanipeter@ku.ac.ke
}

\begin{abstract}
The purpose of this study was to examine the contribution of the German Neukirchen Mission (GNM) in the advent of Western Education in Tana River County, Kenya in the period 1885-1986. The historical research design was preferred as the topic in question was a historical survey of the establishment and development of Western education in Tana River County from late $19^{\text {th }}$ century to the last two decades before the close of the $20^{\text {th }}$ century. Both primary and secondary sources of data were utilized. There were three research instruments namely; interview schedules, Focus Group Discussions (FGDs) and Document Analysis. Both quantitative and qualitative data analysis techniques were utilized though the latter to a larger extent. Documents were analyzed through external and internal criticism. The results revealed that Western education was introduced in Tana River County majorly by the GNM. This was in spite of many hardships and challenges that saw some other Christian missionary organizations like the Swedish Mission, Holy Ghost Fathers (HGF) and United Methodist Mission (UMM) vacate the area to other more friendly locations. The British colonial government equally shied off from the area probably for perceiving it as an area without immediate and direct economic gains to the colony. At independence, of all primary schools in existence in Tana River County, over $90 \%$ of them had been started by the GNM. The four leading secondary schools in Tana River County namely Tarasaa, Hola, Wenje and Ngao all developed out of GNM initiatives. The GNM achieved this even after being deported twice by the British Government during the WW I and WW II which put Germany and Britain in opposing camps. The findings point out the need to acknowledge the role of the German Neukirchen Mission (GNM) in the introduction of Western Education in Tana River County. The findings also show that there is need as much as possible to ensure that differences of political nature are not allowed to affect the provision of vital social amenities like education. The German missioners ought not to have been deported due to the conflict pitting their country and the British at the international level. Moreover, the resilience and success of GNM where everyone else seems to have failed or avoided should be a reference point to stakeholders in education, notably, both the county and the national government on how to improve the education sector in the county and similar arid and semi-arid lands (ASALs).
\end{abstract}

Key words: Advent, Western Education, German Neukirchen Mission 


\section{Introduction}

The nineteenth century is a very critical period in the history of the African continent. This is because it witnessed the coming of Europeans first as explorers and missionaries at the middle of the century, and later as colonizers towards the end of the century. These two events marked a turning point in the continent and their after- effects have shaped the lives of the people of Africa to date.

One of the remarkable milestones resulting from this interaction was the introduction of Western or formal education. It is important to note that this was not the first form of education to Africans, not even the first foreign one. Africans had since time immemorial enjoyed and sustained an informal traditional education based on customs, values and physical environment (Sifuna and Otiende 1994). Islamic education preceded Western education having been introduced along the Eastern African coast back in the seventh century A.D by Arabs fleeing from political and religious persecution back in Arabia (Bogonko 1992).

Furley (1978, p.69) asserts that, "the first Western education reached the Kenyan coast \{East African coast\}in 1498 with the arrival of the Portuguese, amongst them were their own chaplains... whose duties included Christian instruction." This became the second nonindigenous system of education to be introduced in Kenya. East Africa received the attention of more Christian missionary teachers from Europe towards the middle of the $19^{\text {th }}$ century (Barrett et al \{eds\}, 1973 p.30; Furley ibid p. 169).

The introduction of Western or formal education in Africa and Christianity are two historical phenomena that are inextricably intertwined. The 'mondus operandi' of missionaries involved establishing a mission station which encompassed a church, a school and where possible a health centre. As Sifuna and Karugu (1988, p.5) rightly observe, Christian missionaries were an important factor in the development of education in East Africa. They controlled most of the schools with the consequence that areas without missionary influence lagged behind in education.

Although Christianity was first introduced in Eastern Africa by the Portuguese back in the early sixteenth century, Western education never really took root in the region until the arrival of John Ludwig Krapf and Johann Rebmann both of the Church Missionary Society (CMS) in 1844 and 1846, respectively (Anderson 1970, pp.10-11; Barrett et al \{eds\}, ibid; Furley \& Watson 1978, pp. 69-70; Sheffield 1973, pp. 8-9). The CMS was followed by other missionary organizations from Europe sent by mainstream churches like the Roman Catholic Church and the Methodist Church.

In 1884-1885, major European powers met in Berlin, Germany under German Chancellor Otto von Bismark to partition and consequently colonize Africa in what was to later be famously referred as the Berlin Conference. At the Berlin Conference, Tanganyika was one of the colonies given to Germany. However, the partition of the region had not been finalized. Two German brothers Clemens and Gustav Denhardt staked a claim in Wituland on the mainland of Lamu Island. This area subsequently attracted the attention of the Neukirchen Missionary Society (NMS). The Neukirchen Missionary Society (NMS) is the same as the German Neukirchen Mission (GNM). One of the underlying factors for this interest was as a result of the NMS being aware of Methodists' unsuccessful attempt to establish a Galla or Orma Mission. The Galla are Cushitic speaking co-inhabitants of Tana River County together with the Bantu speaking Pokomo. 
The earliest missionaries arrived in Tana River region in 1884 and they were from the United Methodist Free Church. They were followed by the German Lutheran Missionary Society of Neukirchen otherwise known as the German Neukirchen Mission (GNM). In 1888, a Swedish mission was opened only to be abandoned a year later but luckily, the GNM revived it in 1902 . According to Abreu (1982, p.204), the Catholic Holy Ghost Fathers had opened a station in 1889 which they abandoned in 1900. In 1886, the murder of Reverend John and Mrs. Houghton at Golbanti, largely contributed to the withdrawal of Methodist missionaries from the area with the Golbanti station taken over by GNM (Mambo 1980, p.65). According to Nitsch (1914, p.125) in Mambo (1980, p.83), the GNM suffered a loss of 35.4\% of their missionaries which was higher than the losses incurred by the Methodist missionaries. For example, "between 1887 and 1913, 48 brethren and sisters who had served in the Tana field (including Lamu) were recorded to have died, 17 of them in Africa and 14 of them back in Europe with 3 dying soon after their return to Europe while undergoing treatment."

The resilience portrayed by GNM by persevering to continue in an area that other missionary organizations like the United Methodist Mission (UMM), the Holy Ghost Fathers (HGF) and the Swedish mission had abandoned ( this in spite of registering high death rates), calls for the need to examine and document its activities especially in education matters and the impact thereof.

\section{Statement of the Problem}

Western education along the coast of Kenya was introduced in three key areas by the Church Missionary Society (CMS) in Mombasa, the Holy Ghost Fathers (HGF) in Taita and the United Methodist Mission (UMM) in Tana River region (Bogonko 1992). The UMM pioneered the work of introducing formal education in Tana River region together with its sister missionary organization, the Methodist Missionary Society (MMS). Nevertheless, in the late 1890s and early 1900s, it diverted much of its attention to Ribe and Meru. Much has been documented on the Methodists impact in the interior in evangelization and education but there is little said about the German Neukirchen Mission (GNM) which actually took over or replaced UMM when the latter gave up in the Tana River region. The educational work of GNM as the sole missionary organization in a much shunned area deserve to be brought to the fore because existing literature does not appear to have exhausted their contribution in the advancement of formal education.

Most of what there is on missionary work tends to have a bias in favour of the British missionaries. Historians appear to have knowingly or unknowingly relegated anything German to the annals of history probably because of her perceived role in largely triggering the two World Wars. The following excerpt on Tanganyika confirms this state of affairs:

Nevertheless, there were seven other German protestant mission societies in the East African colony whose work has not all been researched in-depth. They were the rather small Bielefeld, Herrnhut, Leipzig, Neukirchen and SchleswigHolstein mission stations as well as the Adventists and the Protestant Africa Society. Together they had 89 stations with 112 missionaries, 76 European helpers- mostly doctors and craftsmen- and 41 mission sisters (Google Books: Neukirchen p.64). 
Any education gains realized in the study region during the colonial period and even beyond must be seen in the light of the role played by the GNM in evangelization and education in the area. The study was intent on giving credit where it is due. The study aimed at uncovering the facts as they were then with regard to the contribution of non-British missionaries to education in the Tana River region in particular and in the country in general. The study identified schools, churches and other institutions that were established by the GNM. It also looked at other activities by the GNM that bore a direct or indirect effect on the establishment of Western education in the study region.

\section{Conceptual Framework}

In this study, several factors came to play, namely: GNM's origin and ideology, GNM's contribution in Western education in Tana River between 1885 to 1986, challenges faced by GNM and the lasting impact of its activities in the Tana River region. The starting point was to seek to understand the connection between GNM's origin and the philosophy or ideology that propelled it in its activities. GNM came from Germany and the congregationists were mainly Lutheran in orientation (Abreu 1982). This was the dominant church in Germany having been founded by Martin Luther, himself a German and renown for spearheading the Reformation movement in the early $16^{\text {th }}$ century. A careful look at the Lutheran doctrine is critical in understanding the GNM as a missionary organization. Other aspects that inform the ideology are The Great Commission, Social Darwinism, Socio-economic and Political factors as well as GNM as a Faith Mission. In addition, an examination of GNM's ideology would shed light on its driving force that propelled its missionaries to come to Africa and endure the hardships that they went through.

The coming of GNM to British East Africa (BEA) is related to colonialism as was the case with other missionary groups. Missionary organizations were sent by mother churches from back home in Europe to Africa and other unreached areas. The activities and the challenges faced by GNM and how the challenges were tackled would inform its ideology as well as serve as a reference point on how to address similar setbacks today especially in education matters. The main activities undertaken by virtually all missionary organizations were establishing churches, schools and hospitals. The GNM Missionaries experienced several challenges, the main ones being inadequate basic needs, tropical diseases, hostile tribes and indifferent British officials. The latter was precipitated by the World Wars which pitted the Germans against the British. The culmination of the study was a critical look at the impact of GNM in education in Tana River County. The impact is presumably positive, measured by identifying learning institutions started by GNM, looking at certain personalities educated by GNM who later served their community as well as the overall transformation of the community at large through Western education introduced by the Missionary Society. 


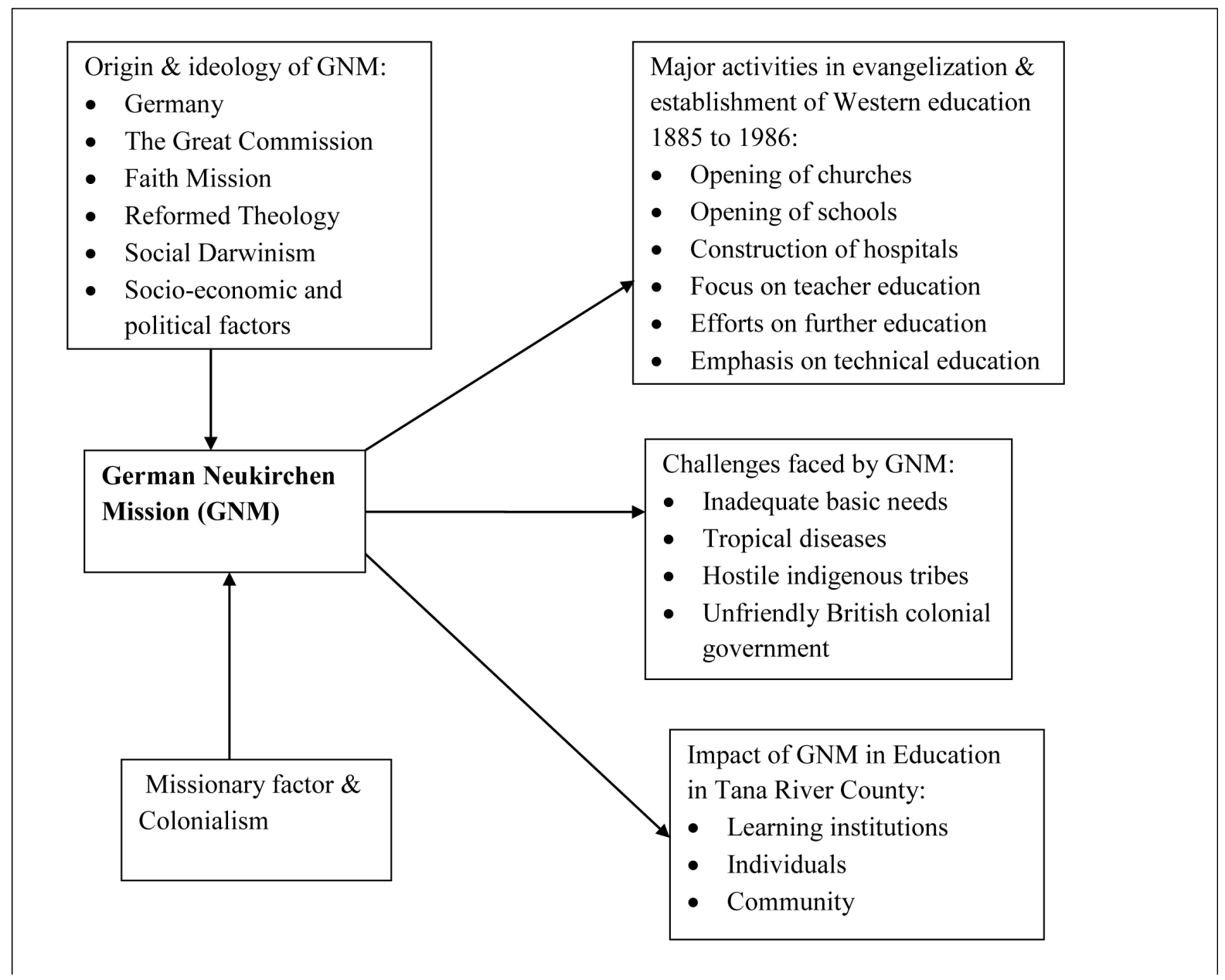

Fig. 1: A Conceptual Framework of GNM's Contribution in the Establishment of Western Education in Tana River County, Kenya 1885 -1986

Source: Researcher, 2017

\section{Review of Related Literature}

At the preliminary stage of missionary work, evangelization went hand in hand with Western education as it was only through the latter that the subjects could understand the Bible, read it on their own and teach others. That explains why the first literature to be translated into local languages was sections of the Bible (Gration 1973, Bantock 1980, Lulat 2005).

The story of GNM must start in 1882 when it was founded (Fahlbusch, Erwin: The Encyclopedia of Religion; Google Books; Nthamburi, 1982, p.49). The founder Pastor L. Doll died in 1883 and was succeeded by Inspector I. Stursberg (Mambo 1980, p.73). The success of GNM in the mission field is associated with Stursberg for his courage and determination. The German Neukirchen Mission (GNM) had started an orphanage back in Germany and it is from this group of youthful men and women that missionaries were sought to reach out the heathen in faraway lands. To show the seriousness of the task at hand, a magazine Die Heidenboten 
(Messenger for the Heathen ) was launched and volunteers ready to go out to proclaim the gospel had to undergo a 3 years training programme. The training entailed Biblical lessons on evangelism, sacrifice and self sufficiency in service for humanity as well as some basic knowledge on African cultures, climate and terrain. Subsequently, two young men were dispatched to Egypt to found a mission station there' (ibid). The fact that the volunteer missionaries had to undergo training clearly shows the keenness with which GNM treated the matter of skills and knowledge acquisition as a prerequisite for success in its endeavours.

In1887, Inspector Stursberg authorized the dispatch of an expedition up the Tana River region under Brother Ferdinand Wurtz. The expedition located Ngao, a Pokomo village, a few miles above the Methodist post at Golbanti. The Neukirchen pioneers soon opened up a post at Ngao (ibid p.75). Ngao became the main base or headquarters from where GNM operated throughout the period they were in the Tana region. Other stations were opened up along the Tana valley. 'These included Kulesa, Makere, Ngatana and Hola to name only a few. At each of these stations, catechist schools emerged' (ibid, p.79). The statement by Mambo (op. cit), "to name only a few" clearly shows that there were more stations and schools opened by GNM hence the need for further study. Nthamburi (op.cit, p.46), on his part' reports that "the Germans opened a chain of stations up the Tana as far as Hola." More needs to be brought to the fore about this chain of stations. This is one of the research gaps which this study wished to fill.

The first African to be baptized was called Abdullah (ibid p.77). By 1894, the number had grown to 8 'who became helpers that is teachers and preachers' (ibid p.79). These had learnt to read and write, could recite the Apostles Creed, the ten commandments and the Lord's Prayer in their mother tongue. The number of converts increased rapidly in the next fifteen or so years after starting off slowly. One key feature of GNM that makes it stand out among other mission groups is the fact that their missionaries never baptized children but preferred to baptize grownups who had learnt to read and write. They believed this made them better converts who could not only read the Bible on their own but also assist in reaching out to others. This policy ensured that their followers embraced Western education faster and at a higher rate when compared to their contemporaries. Nitsch (1914) reports:

In the Neukirchen Mission, the ability to read and write could be ascertained by the number of conversions among the people. Unlike other protestant organizations, the Congregationalists in the Tana mission baptized only those who were fully grown; children were excluded. This practice in effect had the added need for would -be converts to learn to read in order to find the truth in the Bible. In the 1894, 8 youths were baptized. Ten years later in 1904; over 150 people had been baptized. By 1911, 442 had been baptized (Nitsch p.126, Quoted in Mambo 1980, p.79).

The German Neukirchen Mission (GNM) once again portrayed itself as being first among equals when in 1895 it took one of the first eight converts, Amos Tschadoro (Chadhoro), to Germany for further studies. This is probably the first Kenyan or East African to go overseas for further training in the history of this region under the sponsorship of GNM. He undertook a course in seafaring and on returning home in 1896 became the pilot of the mission's boat 
(Nitsch pp79-82 in Mambo, ibid p. 80). This boat became very instrumental in accessing the Pokomo villages that spread along River Tana as the only means of transport those days was mainly by navigating along the river.

The activities of GNM were going on well in the Tana River region until 1914 when the First World War broke out. The War put Germany and Britain in opposing sides which had obviously a negative effect on the work of GNM missionaries who all of a sudden found themselves in enemy territory. The British government did not treat them as innocent or harmless missionaries but declared them persona non grata, consequently, deporting them (Mambo 1980). Of course they reasoned that since the war was also fought in the East African front between the two Europeans powers colonizing the region, patriotism could tempt the missionaries to support the German government in one way or the other. According to Handerson (1962) Germany under General Von Lettow Vorbeck is reported to have given Britain stiff resistance in East Africa despite their superior numbers before finally succumbing to defeat.

In 1926, the British colonial government allowed the GNM to return to Tana River region. During the period of their absence, i.e., 1914 to 1926 the Methodist Missionary Society (MMS) reluctantly took over their work with little or no impact (Gissel \& Gissel 1991). A 1922 MMS delegation felt that they could not inherit the GNM missions because of the cost repercussion bearing in mind that they had opened more stations in the interior of Kenya notably Ribe, Mazeras and Meru (UMC Annual Reports 1914-1925). With much hesitation, MMS accepted to preside over the GNM stations and in 1923 sent Reverend B.J Ratcliffe to Ngao. "However the Reverend was often away on meetings in Meru. He also seemed to lack the funds to do a good job” (Mambo, op.cit p 134).

Mr. W.H Taylor, the acting Inspector of schools at the Coast acknowledged the enormous role played by the GNM in establishing Christianity and Western education in Tana River. The report indicates that the GNM had managed to reach out even to the Galla and therefore appeared to be on the verge of a breakthrough where the Methodist Missionary Society (MMS) had failed. He says in his report:

A large section of the Wa-Pokomo and the Wa-Galla are Christians... This has been the direct outcome of the intensive German missionary effort concentrated over the ten years prior to the outbreak of the Great War. (KNA,Office of the P.C Coast; Sectorisation Report of the Tana River District, 8th July 1929).

Nevertheless, the GNM missionaries appear to have won the hearts of the local people because the Pokomo did their best to sustain the churches and schools GNM had started. The level of consciousness in the value of education instilled among the local people by GNM was high enough to the extent that teachers could work without asking for fees (KNA, Tana River District Annual Report 1916-1917 p.22). The German Neukirchen Mission (GNM) missionaries were allowed back in 1926 after a lot of lobbying both by the mission and the Tana River people. They would work for the next 13 years before another World War outbreak in 1939. On arrival back, the Methodist Missionary Society (MMS) handed over their flock at Golbanti to them (Mambo, op cit p.195). This was an indication that Methodists had completely given up on the Tana region.

In the 1930s, schools in Tana River as well as Ngao Hospital were receiving grants-in-aid from 
the colonial Government courtesy of GNM (ibid p. 192). Grants-in-aid was a Government policy of financially supporting missionaries in providing education to Africans following the recommendations of the Fraser Commission of 1909 (Sifuna \& Otiende op. cit p.193). This was a tremendous contribution by the GNM because had they abandoned the area like other Missionaries, Tana River district would have missed out on the grants -in- aid since without Mission schools the colonial government could not provide any grant- in- aid (Mambo ibid p.208).

From the discussion above, it is clear that by the time GNM missionaries were deported again in 1939 following the outbreak of WW II. Western education gains in the study region can only be credited to these Germany evangelists. Educational losses incurred by their departure, any further educational endeavours embarked on, the number of GNM Schools started that time and lessons to be learnt from GNM missionaries' experiences are research gaps addressed by this study.

\section{Research Design, Research Instruments and Data Collection Techniques}

The study utilized the historical research design since the topic is historical in nature with an aim of unveiling historical facts on education in the study area and study period that are still to be brought to the fore or that need to be clarified, augmented and even corrected. Sources of information were both primary and secondary sources whereas the research instruments were interview schedules, Focus Group Discussions (FGDs) and document analysis.

Primary written sources were mainly found at the Kenya National Archives in Nairobi. Respondents of the research instruments were retired educationists, civil servants and politicians, church leaders and village elders selected through purposive and snowball sampling techniques. A total of 27 of these respondents were interviewed between 2016 and 2017. The study data were coded immediately after collection to ease categorization and ensure necessary clarifications were made where necessary following the suggestions by Miles \& Huberman (1994) on data management. Collected data was analyzed through qualitative and quantitative methods while documents were analyzed through external and internal criticism. External criticism looks at the authenticity or genuineness of a document while internal criticism addresses the accuracy of the contents of a supposedly genuine document (Suter 2006). Documents analyzed in this study included Education Reports, Mission Reports, School Inspection Reports, official correspondences, class registers, Minutes of meetings, baptism cards, photographs and diaries.

\section{Findings and Conclusions:}

\section{GNM's Role in Education from 1887 to 1920}

The Pioneer GNM missionary Rev. Ferdinand Wurtz who arrived in Ngao on 17/3/1887 immediately started offering baptismal lessons in his house to the locals. A church was constructed in 1893 and the classes were moved there to accommodate the growing number of people turning up for the baptismal classes. In 1900, a school was built so that teaching did not have to be done in the church. It is worth noting that the German missionaries did not only teach Religious instruction but from the outset showed affinity for technical/vocational education as well as the 3Rs (Reading, Writing and Arithmetic) It will be remembered that in 1895, Chadhoro Tutu had been taken to Germany to train in mechanics, welding and seafaring 
to be able to sail and maintain the missionary's boat 'Naghea'. This was also confirmed by his grand daughter Mrs. Elizabeth Jato Chadhoro, a resident of Ngao. Five years later, Jillo Kutii also sailed to Germany to train in carpentry and masonry to help in the building and making furniture for GNM churches and schools. His nickname "Mseremala" (Carpenter) attests to this fact. The 1920/21 Tana River District Annual Report indicates that there were about 20 mission schools where the Wa Pokomo learnt reading, writing and the elements of the Christian Religion (KNA/DC/TRD 1/1 1920/21).

\section{The German Neukirchen Mission Role in Education 1926 to 1939}

The sectorisation report of Tana River district dated $8^{\text {th }}$ July 1929 by Mr. W.H. Taylor, Ag. Inspector of schools confirms the above statement about GNM having opened about 20 schools among the Pokomo in which some form of elementary education was being given (KNA/ED. 1/4/3 PC/COAST 2/10/11). The Report has noted that a total of 944 children were in school, translating to $61.1 \%$ of total child population. That was quite an achievement coming at such a time. It will be remembered that the German missioners returned to Tana River in 1926 after their deportation in 1914 and would again be forced to leave in 1939.

A similar inspection on education was carried out in 1932. It is important to note that these inspections and reports were carried out and composed by British government officials and not Germans as the country was under British colonial rule. For them to commend the GNM on its endevours in education meant quite some remarkable progress had been made. This report appreciates some of the German staff like the late Bekker, Reverend Wilhelm May, Fritz Gissel, Steubing and Herman Muller. The number of village schools had increased to 22. The Report shows that the German Neukirchen Mission put emphasis on Girls/Women education at such an early period whereby apart from the usual curriculum of 3 Rs (Reading, Writing and Arithmetic), they were being taught Hygiene, Music, Needlework, Cooking, Child rearing and Sports. Several books had also been translated into Pokomo language namely the New Testament section of the Bible, first Pokomo Reader, An Explanation of Christian Doctrine, Catechism and a hymn book (KNA/DC/TANA RV. 6/1).

Tana River District Annual Reports of 1933 to 1939 consistently indicated that the only education offered in Tana River region was by the Neukirchen Mission. Information gathered at the Kenya Natural Archives (KNA) portray the GNM as having been very keen to adhere to official government policy to the letter probably not to be at loggerheads with the British colonial government which had just allowed them back in 1926 after their deportation in 1914 when the first World War broke out. A letter dated 2 ${ }^{\text {nd }}$ July 1935 from the Education Department Head office in Nairobi indicates that 20 of their schools were officially registered. 
Figure 2: GNM Registered Schools in Tana River by 1935

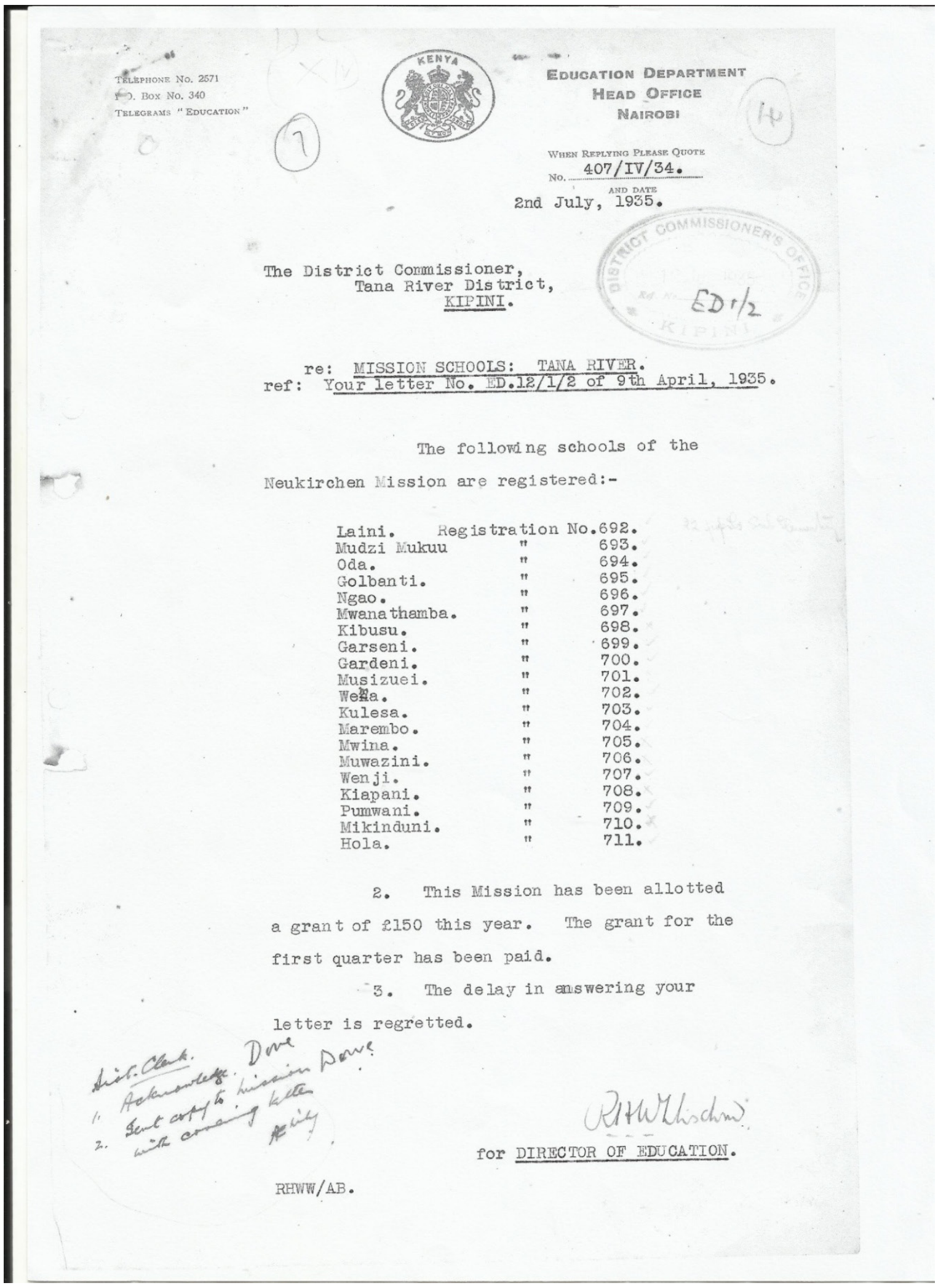

Source: KNA DC / TRD1/2 
In another letter dated $2^{\text {nd }}$ April 1937 to the D.C Tanaland, the GNM through Wilhelm May is informing the D.C of their willingness to plant trees at the open space in front of their schools to commemorate the coronation of 'THEIR MAJESTIES' (Tana River District Annual Reports 1928-1937 KNA DC/TRD 1/ 2). Another contribution to education in Tana River district by GNM was drawing grants-in-aid from the Government to the region which could only be released if an area had a missionary organization in operation.

Mr. Herman Muller had arrived in Tana River district in 1930 and took over as the one in charge of education matters in the district leaving Reverend Wilhelm May to handle spiritual matters (Gissel \& Gissel, 1991). As much as the GNM was commended for conspicuous efforts in matters education in the area, it was criticized for being out of touch with the rest of Kenya in terms of curriculum due to the marginalization of the district. Muller made this issue his first assignment as indicated in the 1939 Tana River District Annual Report;

From 1931 to 1933 the first attempt was made to give the new teachers a methodical teachers training while still the main force remained on Bible training. Of the 7 candidates who came for this course, some have done valuable work (2 have passed the Teacher examination, one became Jean's teacher). In 1935 a course was started in Ngao with 20 boys of different standards with the aim of teachers training on the lines of official syllabus. Of the last mentioned group, 4 finished their teachers training last year and are ready for their examination. 2 received part of their professional training in the Jeans school and passed the E.T examination well" (KNA/DC/TRD/1/3 Tana River District Report 1939).

This first Jean's school trained teacher in Tana River district was Amos Chadhoro who Passed his examination in December 1936 (KNA/DC/TRD/1/2 1928-1937). Muller realized the need to have trained teachers teaching the pupils; that is why he began teachers training at Ngao Hill School and in addition took some of his teachers to Jeans School in Kabete, Nairobi which had been started by the colonial government to train teachers with a bias in technical subjects to teach in African schools.

\section{The GermanNeukirchen Mission InfluenceonEducation 1940 to Independence}

The fast pace of developments in education in Tana River district faced an abrupt setback when WWII broke out in 1939. However, the foundation laid by GNM influenced education in the region for several years long after the Germans had been deported. For instance, Second Term Inspection Report on several schools dated August 1940 by Amos Chadhoro shows that the Pokomo trained teachers continued zealously with the work started by GNM. At the end of the year (1940), the DC wrote to the inspector of schools in Mombasa asking for certificates of teachers who had been trained under GNM and assistance on those who had been continuing with their training by the time GNM left.

In a letter dated 2/12/1940 by Mr. Amos Chadhoro to the D.C Mr. R.G Darroch, the former is informing the district boss of a workshop for teachers he had organized scheduled to run from $1^{\text {st }}$ to $7^{\text {th }}$ January 1941 at Ngao. It is written in Kiswahili but the Researcher has translated it. It reads in part:- 
I am inviting you Sir to attend during the closing ceremony. The teachers will also display items made by pupils. Sir, come ready to address the issue of citizenship. Topics to be covered are:-

1. Arithmetic Method on Sub- standards

2. Swahili Method Standard I \& II

3. Drill/Physical Training

4. Health at Home and in School

5. Geography

6. Tonic Solfa (Music) \{KNA/ DC/TANA RV. 6/1 $\}$

The 1941 Annual Report showed that the government grants to the mission schools continued even after the departure of GNM missionaries and 12 schools were being maintained. The 1943 and 1944 District Annual Reports appreciated that the Pokomo teachers though poorly paid continued with teaching duties with unabated zeal. There was a technical school at Belezoni "where a Pokomo carpenter trained by the Germans and now provided by government with tools (was) supposed to be training a dozen or so of young Pokomo boys." (Handing over Report between P.F. Foster and Captain J.E.H Lambert (DCs) on 27/3/1944). This again affirms GNM's efforts in promoting technical education among the natives.

The British Government was in favour of United Methodist Mission (UMM) taking over GNM missions but the locals were unwilling to embrace the Methodists and instead demanded for the return of the German missionaries. In September 1n 1945, Reverend Archdeacon Beecher of CMS and Rev. A.J Hopkins of Methodist Missionary Society (MMS) visited Ngao but no decision was reached on the way forward.

In 1948, the Education Department accepted responsibility for the payment of all the salaries of the teachers in the primary schools in the district in view of the small income of the Local Native Council (LNC). The Methodist Mission represented by Reverend George Martlew took over missionary activities but never posted any resident missionary, meaning native catechists continued offering spiritual services (KNA, Tana River District Annual Report 1948). Meanwhile, the local people continued resisting being under the Methodists. For instance, in the same year (1948), Reverend Simeon Ubo blocked Reverend Martlew from meeting Neukirchen church adherents at Ngao accusing him of advising the government against the return of GNM missionaries. Reverend Ubo advised Reverend Martlew to handle education matters together with government but stay away from Pokomo spiritual issues. This incident led to temporary withdrawal of grants in aid in Tana River Region as well the refusal to admit Buu (Pokomo) students to Methodist intermediate schools and payment teachers' salaries. In response to this, the local people formed the Young Buu Associaton (YBA) in the spirit of Independent Movement to propagate education with or without European support. Some of the leaders of this movement were GNM trained teachers Israel Gudina and Kaleb Madyawa. Through their appeal to the government, the ban was lifted after one year, grants-in-aid restored and teachers reinstated to work (Kuja kwa Ukristo Tana River p. 16, Abreu, 1982:205, Mambo op. cit. p. 276).

In 1950, there were 23 primary schools all aided in the district (Tana River District Annual 
Report 1950). This means that although GNM missionaries had left in 1939, almost the same number of schools they had left had remained 11 years down the line. The government and the Methodist Missionary Society (MMS) had in real sense not opened any new school. By 1951, the number of schools in the region stood at 24, five of which taught up to standard 5 while pupils in standard 6 and above joined Ribe and Shimo la Tewa in Kilifi and Mombasa respectively. Back in 1949, the Beecher Report had recommended a new education system for Africans, the infamous 4-4-4 i.e. 4 years of lower primary, 4 years of upper primary (intermediate school) and 4 years of secondary education. Consequently an urgent need for intermediate schools arose in the Tana River Region and Ngao as expected became the first intermediate school in the area in 1952. The D.C reported as follows:

The Ngao Intermediate School came into being and despite the high fees was filled. The school is housed in 4 buildings, the old primary school building put up by the German Mission, a new double classroom block and two dormitory blocks. The 3 buildings are 60 by 30 feet. With the exception of 40 drums of cement purchased from DEB funds the whole of this work was done by voluntary labour (KNA Tana River District Annual Report 1952).

There is again clear evidence of local initiatives in the pursuit of education which cannot be divorced from the impetus created by GNM as the 1956 Report continues to lay bare the authenticity of this claim. It says in part:

There is a continuous demand for compulsory education from an influential section of the people in Ngao and Salama locations headed by the teachers.... In Salama location, the advocates of compulsory education even went so far as to try to compel parents to send their children to school by withdrawal of fishing rights (KNA Tana River District Annual Report 1956).

Demand for greater opportunities for intermediate education continued. Right from 1955 discussions regarding a second intermediate school at Hola had kicked off. Hola was another Mission Station in the Upper Tana started by the GNM. This initiative bore fruit in 1958 when Hola become the second intermediate school in Tana River Region (KNA, Tana River District Annual Report 1960 p. 13). This fact is also confirmed by minutes of the DEB meeting held on $26^{\text {th }}$ February 1959 at Garsen (KNA/CD/4/4). Save for the Europeans, membership of the DEB comprised Pokomos educated by GNM - Ezekiel Jara, Joseph Bahola, Paul Pakia, Aser Benjamin, Israel Gudina, Mrs. Luice Pakia and Seth Meshak. All schools had been put under the DEB in 1955 when the Methodist Missionary Society (MMS ) even with the moral support of the government decided that the wisest counsel was to quit superintending the Tana River schools (KNA Tana River District Annual Report, 1955 p.21). A look at the list of 26 DEB/Aided schools in Tana River district in 1958 again is dominated by the same schools that were started by GNM.

Wenje became the third intermediate school in the district in 1960. The GNM had way back in 1897 purchased the Wenje Mission from Swedish missionaries. According to a Methodist 
Church pastor (81 years of age) of Makere ya Gwano/Wenje, also a retired teacher, the Swedish gave up on the Tana and left for Somaliland with some converts from Kulesa village. He got this information from his father who had worked closely with GNM. Therefore, on the eve of independence, Tana River district had 3 intermediate schools namely Ngao, Hola and Wenje all having grown from the elementary schools started by GNM (Tana River District Annual Report 1960, p. 13).

\section{The German Neukirchen Mission Influence in Education from Independence to 1980 s}

In the early 1960s, Mr. Amos Chadhoro spearheaded a move to register the Tana Independent Church. This would bring together Christian converts who wanted to continue identifying with GNM. His efforts never materialized. Together with the other church leaders from Garsen, Itsoe, Furaha, Mwanadhamba and Ngao, they wrote letters to the P.C Coast Province and Neukirchen Mission Director in Germany asking for the return of the GNM to Kenya. The letters are dated $22^{\text {nd }}$ July 1965 (KNA/CD/4/4 pp.99-100). This initiative bore fruit and GNM missionaries were allowed back to the county. The Researcher met one of the adherents of GNM who personally met Herman Muller on his return to Kenya. The man who met Muller in Mombasa in 1965 told the Researcher:

What surprised me was how Herman Muller could still communicate in fluent Kiswahili and Kipokomo having left Kenya in 1939. I kept wondering whether he really ought to have come back after so many years. A lot had happened and changed. Most of us had already joined Methodist and other churches; personally, I was already a minister with the Methodist at Kongowea, Mombasa. Muller wanted me to go with him to Tanzania where GNM had a theological college, study for 3 years than come back and preside over AIC Mombasa. I declined. He was disappointed (Interview done at Makere ya Gwano/ Wenje on $18 / 10 / 2017)$.

On education matters, a retired teacher and former Tana River District Kenya National Union of Teachers ( KNUT) Secretary general reveals that the GNM missionaries who returned led by Herman Muller organized in 1966 to send 100 Pokomos to Germany for further studies. They were selected from class 8 to form four and would train in fields like Agriculture, Education, and Medicine at different levels depending on individual entry behaviour. Their passports were processed but the much anticipated trip failed to materialize. He was one of them and felt quite disappointed. Unconfirmed reports pointed fingers to the Methodists who advised the newly independent government against allowing such an undertaking since such a big number could come back and oppose the government or initiate secession plans of Tana River district breaking off from the rest of the country. One wonders why the government could turn down such an initiative bearing in mind that in the late 1950s and early 1960s Tom Mboya, Julius Gikonyo Kiano and Jaramogi Oginga Odinga had taken dozens of Kenyans to the USA, USSR and Europe for university studies through the famous "Airlifts". These graduates would later return to Kenya, pick up senior managerial, technical and administrative jobs in the government and 
transform their lives and those of their communities as well as fill critical positions in the civil service left by Europeans who left after after independence.

The churches in Ngao, Mwanadhamba, Furaha and Garsen were denied permission to form the Tana Independent Church and consequently they were advised by GNM office in Germany to partner with the African Inland Church (AIC) in 1967. The African Inland Church (AIC) was a product of the Africa inland Mission (AIM) with its roots in USA (Welbourn 1965, p.63) and was similar to the GNM in the sense that it was a "Faith Mission" (Nthamburi 1982, p. 55). Faith Missions drew members from different denominations and relied on personal donations or well wishers' support for upkeep and not specific sponsor churches. In 1968, Tarasaa High school was established under the sponsorship of the African Inland Church (AIC). According to the retired teacher and KNUT official, the school was started at Ngao and operated for 3 years but was later moved to Tarasaa $3 \mathrm{~km}$ towards the Garsen-Malindi road. The first principal was Mr. Tola Kokote Bonaya. The first Board of Governors (BOG) Chairman was Mr. Israel Gudina son of Gudina Kanana, one of the first 8 GNM converts. Germans assisted financially in the school's construction and continued for a number of years offering help. Abreu (1982) reports:

In 1968, the Buu embarked on their self-help secondary school (harambee): Tarasaa school was built and later taken over by the government. It has a Harambee education scheme to which the German 'Bread for the world' organization contributes generously" (Abreu op cit p.207).

In 1970, more GNM missionaries visited Tana River district and in the following year they started constructing a new church at Ngao because after a protracted battle, the old one had been taken over by the Methodists. The church was officially opened in 1979 by president Moi in the company of Bishop Wellington Mulwa of the African Inland Church (AIC). The people of Ngao changed the name of Ngao primary school to Arap Moi Primary School in honour of the president's visit (Gissel \& Gissel 1991). In 1985, former beneficiaries of Western education provided by the GNM conceived an idea to establish a secondary school at Ngao to accomplish Mr. Herman Muller's long cherished dream of building a secondary school of the calibre of Alliance High School. This group was led by Mr. Yuda Komora who had been a teacher, Education officer, Director of Education and permanent secretary in Government together with Mr. Lisania M. Buya, a long serving teacher, Head Teacher and Education Officer. Another person in this team was Mr. Permena Mungatana, a long serving teacher who even gave part of his land for the construction of the school. This initiative came to fruition in 1986 when Ngao secondary school opened its doors for the pioneer form one class under the newly introduced 8-4-4 system. The founding principal was Mr. Kenneth P. Pakia, the first born son of J.M. Paul Pakia. (Article: A brief History of Ngao Girls Secondary School by Lisania M. Buya, Flezian Kamora and Tola N. Daddah). 


\section{ASummary of GNM's Contribution in the establishment of Western Education in Tana River County, Kenya 1885-1986}

\begin{tabular}{|c|c|c|c|c|c|}
\hline $\mathbf{S} / \mathbf{R}$ & ITEM & \multicolumn{4}{|c|}{ NUMBER } \\
\hline 1. & Books written/translated for Pokomo learners & \multicolumn{4}{|l|}{5} \\
\hline \multirow[t]{2}{*}{2.} & Approximate number of people baptized & By 1894 & 1904 & 1911 & 1940 \\
\hline & upon completion of baptism classes & 8 & 150 & 442 & 3600 \\
\hline 3. & Number of primary schools opened & \multicolumn{4}{|l|}{29} \\
\hline 4. & Number of intermediate schools opened & \multicolumn{4}{|l|}{3} \\
\hline 5. & Number of secondary schools opened & \multicolumn{4}{|l|}{4} \\
\hline 6. & Number of technical schools opened & \multicolumn{4}{|l|}{2} \\
\hline 7. & $\begin{array}{l}\text { Number of people sent to Germany for } \\
\text { further studies }\end{array}$ & \multicolumn{4}{|c|}{$\begin{array}{l}4 \quad * 100 \text { blocked from going by the } \\
\text { government in } 1966 .\end{array}$} \\
\hline 8. & Curriculum focus (Apart from Religion) & \multicolumn{4}{|c|}{ 3Rs- Reading, Writing \& Arithmetic } \\
\hline 9. & Girls' School & \multicolumn{4}{|l|}{1} \\
\hline 10. & Teachers' College & \multicolumn{4}{|l|}{1} \\
\hline
\end{tabular}

\section{Recommendations}

The researcher hopes that these findings will add more information on the existing body of knowledge on the role of missionaries and Africans in the establishment and development of Western education in Kenya. Secondly, there is need to co-exist in peace and solve conflicts amicably when they do arise so that vital services like education are not negatively affected. Based on the findings of the study, it is clear that going by what the GNM had achieved in education, it ought to have been allowed to continue operating in the area. Education is a complex phenomenon whose success depends on several stakeholders coming together. Governments should ensure this vital sector is not compromised due to conflict or political differences. Organizations supporting education like Faith Based Organizations (FBOs) and Non-Governmental Organizations (NGOs) should be allowed to continue in this noble work during conflict in the same way The Red Cross offers humanitarian aid in battle prone areas. Additionally, no area should be marginalized or sidelined by the government of the day as pertains availing social amenities like education. The colonial government in Kenya invested little in the Arid and semi-arid areas (ASALs), Tana River County included. Finally, The resilience, sacrifice, forecast, patience, innovativeness, forthrightness and positive attitude of the GNM is a clear indication that all areas in a country can be made to compete favourably in all sectors of the economy if given the required support. 


\section{References}

Anderson, J. (1970). The struggle for the school. Nairobi: Longman.

Bantock,G.H. (1980). Studies in the History of Educational Theory V.1 Artfice E Nature 13501765. London: George Allen \& Unwin.

Barrett,D.B.,Mambo,G.K.,Mclaughlin,J.,McVeigh,M.J (eds) (1973). Kenya Churches Handbook:The Development of Kenyan Christianity 1498-1973, Kisumu: Evangel Publishing House.

Bogonko,S.N (1992). A History of modern Education in Kenya (1895-1991). Nairobi: Evans Brother. Press.

(1992). Reflections on Education in East Africa Nairobi: Oxford University

Bonaya, T.W (1969). The Young Buu Association 1944-1956 in Mc Intosh (ed). Nairobi Historical Studies I: Ngano. Nairobi: EAPH.

Erwin, F. The Encyclopedia of Religion: Available at www.googlebooks (Last seen 11-5-2016)

Furley, D.W (1978). A History of Education in East Africa. New York: NOK Publishers.

German Colonialism: Race, The Holocaust E Postwar Germany P.64: Available at

www.googlebooks (Last seen 11-5-2016)

Gissel,F. \& Gissel, H (1991). Einbundert Jabre Neukirchen Mission am Tana 1887-1987 (A Hundred Years of Mission in Tana: The Neukirchen Mission in 1887-1987). Saarbrucken: Homo ET Religion.

Gration,J.A (1973). The Relationship of the African Inland Mission and its National Church in Kenya 1895 and 1971. Unpublished Ph D Dissertation, New York University.

Handerson,W.O (1962). Studies in German Colonial History. London: Frank Cass.

KNA / CD / 4/4. Minutes of a DEB meeting in 1959.

KNA/DC/TANA Rv.6/1.Letters by Amos Chadhoro to DC Tana River and the GNM Office in Germany. 1965

KNA/ED/1/4/3. Colony and Protectorate of Kenya Office of P.C Coast, Mombasa PC/ Coast/2/10/11, 1929

Lulat,Y.G.M. (2005). A History of African Higher Education from Antiquity to the Present: A Critical Synthesis. Westport:Conn Praeger

Mambo, R. M (1980). Challenges of Western Education in the Coast Province of Kenya, 1890-1963. Ph.D Dissertation, Columbia University.

Miles,B.M \& Huberman,A.M (1994). Qualitative data analysis: A resource book of new methods. Beverly Hills. Sage Publications.

Nthamburi, Z.J (1982). A History of the Methodist Church in Kenya. Nairobi: Uzima Press Ltd.

Oso, W.Y \& Onen, D. ( 2009), A General Guide to Writing Research Proposal and Report. Nairobi: Jomo Kenyatta Foundation.

Sheffield, J.R (1971). Education in the Republic of Kenya. Washington: USA Government Printing Office.

Sifuna D.N \& Karugu A.M (1988). Contemporary issues in Education in East Africa: Series on Provision of leadership in Teacher Education supported by O.D.A Through British Council 
HED Section. Nairobi: Kenyatta University.

Sifuna, D.N (1990). Development of education in East Africa: The Kenyan Experience. Nairobi: Initiative Publishers.

(1995). "Historical Research in Education" in Kilemi Mwiria \& Wamahiu S.P

( eds). Issues in Educational Research in Africa. Nairobi: East Africa Educational Publishers.

Suter,W.N (2006).Introduction to Educational Research. London: Sage Publications, Inc.

Tana River District Annual Report 1917-1926. KNA DC / TRD 1/1.

Tana River District Annual Report 1928-1937. KNA DC / TRD 1/2.

Tana River District Annual Report 1938-1950. KNA DC / TRD 1/3.

Tana River District Annual Report 1951-1956. KNA DC / TRD 1/4.

Tana River District Annual Report 1957-1963. KNA DC / TRD 1/5. 